\title{
Press, Community, and Library: A Study of the Chinese-language Newspapers Published in North America
}

\author{
Tao Yang \\ Rutgers University \\ United States \\ taoyang@rci.rutgers.edu
}

\begin{abstract}
Often classified as ethnic press or immigrant press, hundreds of Chinese-language newspapers have been published in North America since 1850s. This paper presents the preliminary results of a comprehensive study of this unique genre of publication. After a brief introduction, this paper offers some general observations about the relationships between the Chinese community and its press. Then it proceeds to outline the historical development of the Chineselanguage press in North America. A snapshot of the contemporary newspaper is also provided, with examples from two metropolitan areas: the New York CityNew Jersey metropolitan area in the U.S. and the Greater Toronto Area in Canada. At the end of the paper, issues relevant to the library community are discussed.
\end{abstract}

\section{Introduction}

"At the entrance to the Princeton branch of the Asian Food Market, half a dozen free Chineselanguage newspapers are stacked next to the usual supermarket offerings..." (Kwong \& Miscevic, 2005, p. 401). With a vivid account of the Chinese-language newspapers circulating in Princeton, New Jersey, Kwong and Miscevic began the final part of their highly acclaimed book on Chinese American history. They continued to describe the content of the papers and concluded that the "papers serve as focal points for Chinese speakers in the geographic areas they cover, and by dispensing information about the needs of their readers and the services and opportunities offered them, they make the otherwise disconnected Chinese immigrants feel that they in fact belong to a community" (ibid, p. 402).

Today, it is a common scene in the Asian grocery stores in New Jersey that a number of Chinese newspapers are stacked at or near the entrance; the origin of which may be traced back to mid1990s when the New York Times first reported that a "press war" was happening among Chinese newspapers in New Jersey (Chen, 1995). I first witnessed this phenomenon in the fall of 2007 when relocating to New Jersey. Since then, I have had the opportunity to examine these newspapers from the perspectives of a consumer as well as an information professional. This study of the North America-based Chinese newspapers stems also from my previous experience working with the English-language newspapers and periodicals published in the pre-Communist China (Yang, 2005).

New Jersey is far from unique in terms of seeing the proliferation of Chinese-language newspapers. Currently, several Chinese-language dailies such as the World Journal (世界日报) are distributed across the United States and Canada. Community-based press is revived in old Chinatowns and burgeoning in new "ethnic suburbs" where a large number of Chinese are 
moving in (Li, 1998). Correspondingly, the study of Chinese-language press has become a multidisciplinary endeavor, drawing interests from both social scientists (Zhou, Chen, \& Cai, 2006; Lin \& Song, 2006) and historians (Lai, 1987 \& 1990). Since the publication of a union list of Chinese-language newspapers in North America (Lo \& Lai, 1977), the library community has paid considerable attention to this type of publication, but more challenges remain, due to both its prolific nature and the increased research interest.

In the following, I will first provide some general observations about the relationship between the Chinese community and its publications. Then, drawing information from the existing literature, I will outline the historical development of the Chinese-language newspapers in North America. A snapshot of the contemporary newspaper will also be provided, largely based on my own investigations of newspapers circulating in two metropolitan areas: the New York City-New Jersey metropolitan area in the United States and the Greater Toronto Area in Canada. At the end of the paper, I will summarize the issues pertinent to the library community.

\section{People and Press: General Observations}

When talking about the Chinese living in North America, we should remind ourselves that this is a diverse group in terms of spoken language, educational background, economic status, geographic origin, and political attachment. Therefore, their relationships with the newspapers vary accordingly.

Many Chinese Americans or Chinese Canadians who grew up in North America may not be able to read Chinese. To them, the Chinese-language newspapers, as a source of information, may be insignificant. But to those who work in businesses or provide professional services, the newspapers provide a venue to reach potential ethnic customers.

Due to the continuous waves of immigration during the last several decades, the first-generation immigrants still make up the majority of Chinese population in North America. New immigrants arrive via different tracks. Professional workers enter the workforce in the United States or Canada after finishing college and, more often, postgraduate training. Therefore, they may have acquired sufficient English-language skill. To them, Chinese newspapers may complement or supplement the English-language media they are able to access. Seniors and unskilled workers usually come under family sponsorship. Most of them may have to rely on the Chinese newspapers heavily and even exclusively for information about the outside world. Increasingly, affluent immigrants seek permanent residence through their business investments. And the Chinese newspapers present a unique advertising opportunity to them.

Chinese speakers who came from different geographic areas often develop subgroups, due to linguistic and/or political barriers. Those who came from Hong Kong, a British colony until 1997, and its neighboring Guangdong Province, often prefer to speak Cantonese, which is next to impossible for the Mandarin speakers to understand. Mandarin is the standard language in both the mainland China and Taiwan, but the hostility and distrust between mainland and Taiwan since 1949 is a barrier that takes time to overcome, even in North America. Understandably, ethnic Chinese who came from Southeast Asia consist of another distinctive subgroup. Many of them arrived as refugees in the 1970s and 1980s. Political rifts further divide the Chinese 
community along the fault lines such as the issues of Taiwan independence and Falun Gong. All these divisions create diverse or even conflicting demands for the content of the newspapers.

Given all these divisions, one of the few common characteristics that most Chinese immigrants do share is the ability to read Chinese text. But even that is problematic. In Hong Kong and Taiwan, the traditional Chinese characters remain to be the standard writing system but the mainland China adopted the so-called "simplified characters" half a century ago. Therefore, the immigrants from Taiwan or Hong Kong read the traditional characters whereas the mainlanders prefer to use simplified characters, even though they can recognize most of the traditional characters. So the Chinese newspapers published in North America have to decide which character set to use in order to appeal to the subgroup(s) they want to reach.

Needless to say, the above analysis is necessarily generalized and even overly simplified. Many other variables could also affect an individual's relationship with a newspaper, but hopefully this analysis has demonstrated the complexity between the ethnic Chinese and their newspapers. It may serve as a point of departure when we discuss the development of Chinese-language newspapers as a genre, from its beginning in the 1850s to today.

\section{History of Chinese-language Newspapers in North America: An Outline}

Available evidence suggests that the first Chinese newspapers in North America appeared in 1850s, shortly after the initial wave of Chinese labors entered California during the Gold Rush, primarily from Guangdong. There were several hypotheses as to the exact title and the beginning year of the very first newspaper, but today most scholars agree that the Golden Hills' News (金山日新录) is the first Chinese-language newspaper in North America. It started in San Francisco in 1854, probably on April 22, as Karl Lo concluded in a painstakingly detailed analysis (Lo, 1971). The Golden Hills' News was established by American missionaries working with Chinese labors in San Francisco. In the April 29 issue of the newspaper, a note in English, supposedly from the publisher Howard, indicated that the Golden Hills' News was created for a new Chinese Mission Chapel and the "influence of chapel and press is intended to relieve the pressure of religious ignorance, settle and explain our laws, assist the Chinese to provide their wants and soften, dignify and improve their general characters" (quoted in Lai, 1977, p. 28).

A digitized copy of the May 27, 1854 issue of the Golden Hills' News is available in California Digital Library (original copy is in the collection of the California Historical Society). That issue consists of four pages, printed on a single sheet of paper and folded in the middle. On the first page of that issue, there is a small piece written in English titled "Chinese Exodus", in which the author called the "(m)erchants, (m)anufacturers, (m)iners, and (a)griculturists" to come forward as the friends of the Chinese "so that they may mingle in the march of the world, and help to open for America an endless vista of future commerce" (Anonymous, 1854). Similarly, the first Chinese piece written by an author Li suggested that this newspaper can provide some small help to the Chinese through facilitating business, providing knowledge, conveying popular opinions, and communicating governmental issues ( $\mathrm{Li}, 1854)$. The other pieces, all written in Chinese, are different types of news items, including ship arrival or departure dates, prices of commodities, local news, and news related to the United States, China, and other parts of East Asia. 
The Golden Hills' News probably only existed for a few months, but it is significant as the first ethnic Chinese newspaper (see discussion in Wilson, Gutierrez, \& Chao, 2003, pp. 280-285). Among other things, it is believed that the Golden Hills' News probably established a technical standard for Chinese newspapers that was in use until the turn of the century (Lai, 1990). Shortly after the demise of the Golden Hills' News, another missionary publication, The Oriental (东涯新录), started publishing in January 1855 by Reverend William Speer, who happened to belong to the same Chinese Mission Chapel that sponsored the Golden Hills' News. The Oriental included an English section. It ceased publishing at the end of 1856. The first Chinese-run Chinese newspaper, Chinese Daily News (沙架免度新录), began publishing in 1856 in Sacramento, California and continued until 1858, even though not much else is known about it (Lo \& Lai, 1977). Several papers published in 1870s and 1880s sampled by William E. Huntzicker (1995) are remarkably similar to the Golden Hills' News in terms of content. Take San Francisco China News (旧金山唐人新闻纸, 1874-1875) for example. It was published weekly and covered prices of commodities, shipping news, statistics of imports and exports, advertisements, editorials, tabloid-type stories, and China-related news (Huntzicker, 1995).

The end of 19th century saw the increase of interest in China politics in the Chinese newspapers in North America, as various political factions in China sought to compete for the influence over and the support of overseas Chinese through publishing. Chinese Reform Gazette (日新报 or 新报, Vancouver 1903-1911), the first Chinese-language newspaper in Canada, belongs to this category. It was launched by the Chinese Reform Association, which pursued the goal of reforming China while preserving the Manchu monarchy until the revolution of 1911 overthrew the Manchu government. The revolution of 1911 was led by Dr. Sun Yat-sen and his Revolutionary Party. Dr. Sun attracted a large number of followers among the Chinese living in North America and might have direct influence over the revolutionary organ The Youth (later Young China, 少年中国晨报) in San Francisco (Wen, 2005). Both the reformists and the revolutionaries published various newspapers to promote their own agendas and argue against the other side.

In 1927, the Chinese Nationalist Party, the successor of the Revolutionary Party, established a national government in Nanjing, which ruled China until 1949. During that period, most Chinese newspapers in North America previously favoring the opponents of the Nationalists either ceased publishing or transferred control to various Nationalist factions. The most notable exception is the Chinese Times (大汉公报) in Canada, which was controlled by the Chinese Free Masons, a quasi-political party, and stayed in business from 1914 to 1992, making it one of the longest running Chinese newspapers in North America. In the late 1940s, the Nationalists engaged in the civil war with the Chinese Communists. When the defeat of the Nationalists seemed inevitable, the pro-communist voices started to surface in the Chinatown newspapers. But they were subsequently suppressed and prosecuted by the Nationalists and the United States government that supported the Nationalists (Lai, 1990).

Ironically, when the political forces in China dominated the Chinatown newspapers in North America during the first half of 20th century, one of the most popular newspapers in that period was Chung Sai Yat Po (中西日报), a newspaper that was unaffiliated with any Chinese political parties for most of its life. The early success of Chung Sai Yat Po may be attributed to its focus 
on community issues and its promotion of the integration of Chinese immigrants into the American society (Sun, 1998). Later, Chinese Pacific Weekly (太平洋周报, San Francisco, 1946-1979), another influential community press, adopted similar non-partisan stances (Zhao, 2006). It is also worth noting that some Chinese-language dailies such as Chung Sai Yat Po and Mong Hing Yat Po (文星日报, San Francisco, 1891-1969) published quality literary works written by immigrants. Those literary works, when rediscovered in the 1970s, became important sources for studying the early Chinese American literature (Kwong \& Miscevic, 2005, pp. 304305).

Generally speaking, the Chinese-language press was in decline from the end of World War II through the 1960s, for both political and demographic reasons. The hostility between the Communist China and the West and the anti-communist sentiment in North America, particularly the anti-communist McCarthyism of 1950s in the United States, might have silenced a generation of ethnic Chinese. In terms of demography, many younger generations of the Chinese born in North America were unable to read Chinese, while very limited number of new immigrants arrived during that period. At that time, the Chinese newspapers appeared to be "doomed to eventual extinction", as observed by Lai (1977).

In 1960s, while the established Chinatown newspapers were in decline, a new type of Chinese press entered North America from Hong Kong and later Taiwan and gradually achieved nationwide prominence in both the United States and Canada. Sing Tao Daily (星岛日报), a Hong Kong-based newspaper, made one of the earliest efforts to enter North America (Leung, 2007). In 1961, Sing Tao Daily began distribution in San Francisco through airmail on daily basis. Two years later, it started printing in San Francisco. In the subsequent years, Sing Tao Daily developed local editions in New York, San Francisco, Los Angeles, and Vancouver and is now distributed across much of the United States and Canada. The most important press from Taiwan is the World Journal (世界日报), which was established in 1976 by Wang Tih-Wu, who was the owner of United Daily (联合日报) and also a high-ranking member of the Nationalist Party in Taiwan.

Joseph Leung (2007), Sing Tao's current Editor-in-Chief in San Francisco, differentiated three periods in the development of Sing Tao Daily in North America: nostalgia period (1960s-1970s), localization period (1980s-1990s), and global Chinese network period (21st century), which may be applied to the World Journal and other similar publications. Leung (2007) also attributed the success of Sing Tao Daily in North America to its advantages over the older Chinatown presses in terms of business model, available capital, and content coverage. But the ultimate reason for the success of this new type of transnational press may be the steady increase of Chinese immigrants during the last several decades, due to the favorable changes of the immigration laws in the United States and Canada in the 1960s, the improved relations with China in the subsequent years, and the economic and political developments in China, Hong Kong, and Taiwan that generally facilitate emigration.

\section{Contemporary Chinese Newspapers in North America: A Snapshot}

Today, the Chinese press in North America mainly consists of two types of newspapers: (a) major dailies that are distributed nationwide, and (b) numerous community papers that serve 
local Chinese population, while a few newspapers do not fall into either category easily. All of the major newspapers are distributed via paid subscriptions or sold at retail places while the community papers are usually free to consumers.

Table 1 lists the names and web addresses of four major Chinese dailies, their circulation numbers, and their transnational affiliation as well as the year they established a North American edition (Sing Tao Daily and Ming Pao had begun distributing and printing in North America long before their North American editions).

Table 1: Major Chinese-language Daily Newspapers in North America (adapted from Zhou et al., 2006)

\begin{tabular}{|c|c|c|c|c|c|}
\hline & $\begin{array}{l}\text { Circulation } \\
\text { in the U.S. }\end{array}$ & $\begin{array}{l}\text { Circulation } \\
\text { in Canada }\end{array}$ & $\begin{array}{l}\text { Transnational } \\
\text { Connections }\end{array}$ & $\begin{array}{c}\text { Year } \\
\text { Establishing } \\
1^{\text {st }} \text { North } \\
\text { American } \\
\text { Editions }\end{array}$ & $\begin{array}{l}\text { Local } \\
\text { Editions }\end{array}$ \\
\hline $\begin{array}{l}\text { World Journal } \\
\text { 世界日报 } \\
\text { wwww.worldjournal.com }\end{array}$ & 298,500 & 25,000 & $\begin{array}{l}\text { Affiliated with } \\
\text { United Daily in } \\
\text { Taiwan }\end{array}$ & 1976 & $\begin{array}{l}\text { New York, } \\
\text { Los Angeles, } \\
\text { San Francisco, } \\
\text { New Jersey/ } \\
\text { Philadelphia, } \\
\text { Boston, } \\
\text { Chicago, } \\
\text { Washington, } \\
\text { D.C. } \\
\text { Atlanta, } \\
\text { Toronto, } \\
\text { Vancouver }\end{array}$ \\
\hline $\begin{array}{l}\text { Sing Tao Daily } \\
\text { 星岛日报 } \\
\text { www.singtaousa.com } \\
\text { wwww.singtao.ca }\end{array}$ & 181,000 & 40,000 & $\begin{array}{l}\text { Affiliated with } \\
\text { Sing Tao } \\
\text { Group in Hong } \\
\text { Kong }\end{array}$ & 1975 & $\begin{array}{l}\text { San Francisco, } \\
\text { New York, } \\
\text { Los Angeles, } \\
\text { Toronto, } \\
\text { Vancouver, } \\
\text { Calgary }\end{array}$ \\
\hline $\begin{array}{l}\text { China Press } \\
\text { 侨报 } \\
\text { www.usqiaobao.com }\end{array}$ & 120,000 & N/A & $\begin{array}{l}\text { Maintaining } \\
\text { close ties with } \\
\text { the mainland } \\
\text { China }\end{array}$ & 1990 & $\begin{array}{l}\text { Los Angeles, } \\
\text { New York, } \\
\text { San Francisco }\end{array}$ \\
\hline $\begin{array}{l}\text { Ming Pao Daily News } \\
\text { 明报 } \\
\text { www.mingpaona.com }\end{array}$ & 100,000 & 35,000 & $\begin{array}{l}\text { Affiliated with } \\
\text { the Ming Pao } \\
\text { Enterprise in } \\
\text { Hong Kong }\end{array}$ & 1993 & $\begin{array}{l}\text { New York, } \\
\text { San Francisco, } \\
\text { Toronto, } \\
\text { Vancouver }\end{array}$ \\
\hline
\end{tabular}

Among these four papers, World Journal is unquestionably the leader in terms of both total circulation number and the geographic coverage. Sing Tao Daily and Ming Pao have appeals to immigrants from Hong Kong; historically Sing Tao Daily was pro-Taiwan while Ming Pao was 
more sympathetic toward mainland China (Lai, 1990), but today that difference may be diminishing. China Press claims a niche market with extensive coverage of mainland China, but its presence in Canada seems to be at the minimum.

All of these major dailies are either formally affiliated with media organizations in Taiwan (World Journal) or Hong Kong (Ming Pao and Sing Tao Daily) or have maintained informal ties with the authority in mainland China (China Press). This has been an issue of contention for other newspapers with no such ties. For example, Lai (1990) described the protests against the World Journal by the editors of smaller Chinese newspapers when it was first launched in 1976. The transnational connection is also a source of confusion for outside observers. There is an interesting case in point. In early 2007 when the United States Senator Hillary Clinton was in San Francisco to raise money for her failed presidential campaign, her campaign staff excluded reporters from China Press, Sing Tao Daily, and World Journal from entering the fund-raising event but they did let the Ming Pao journalist in. When the journalist from the World Journal who has been working in the San Francisco area for two decades complained, a Clinton staffer responded that she was considered to be from "foreign media", of which only a single pool reporter could be admitted. After the World Journal and other Chinese media publicized the story, the Clinton campaign apologized and promised to update its press list (Hua, 2007). My own perspective on this issue is that these major dailies should be considered part of the ethnic Chinese press, given their extensive efforts to cover issues interesting to the Chinese communities in North America.

In addition to these four major dailies, some other newspapers also strive for nationwide distribution. International Daily News (国际日报, Los Angeles, 1981- ) is sometimes regarded as a major paper, but it does not have a substantial presence outside of California. International Daily News is currently also the publisher of the Overseas Edition of People's Daily (人民日报), a mouthpiece of the Chinese government, and the North American Edition of Wei Wei Po (文汇报), a pro-PRC newspaper in Hong Kong, but both papers only reprint selective contents from home editions and have no local news. So they should not be confused with the majority of Chinese newspapers published in North America.

Some special interest publications in newspaper format are also able to reach audiences across North America. But their value as news source is not the same as the major newspapers aforementioned. Herald Monthly (号角月报), a Christian publication by New York-based Chinese Christian Herald Crusades, is widely distributed in the United States and Canada, but it has minimum coverage of current affairs. Epoch Times (大纪元时报), a weekly publication of Falun Gong with numerous local editions, does report current news, but usually through the lens of Falun Gong. Both are freely available in retail outlets.

It is impossible to list all the local community papers, given their sheer number. Instead, I will use the newspapers from two metropolitan areas as examples. Table 2 lists the papers from the New York-New Jersey metropolitan area, and Table 3 lists the papers from the Greater Toronto Area. I must acknowledge that the information about papers in Toronto is incomplete due to the difficulty of collecting information remotely. 
Table 2: Local and Regional Chinese-Language Newspapers and Periodicals (New York-New Jersey Metropolitan Area)

\begin{tabular}{|c|c|c|c|c|c|c|}
\hline Title & Frequency & $\begin{array}{l}\text { Distribution } \\
\text { Method }\end{array}$ & $\begin{array}{c}\text { Year } \\
\text { Founded }\end{array}$ & Circulation & Office & Source \\
\hline $\begin{array}{l}\text { Asian American Times } \\
\text { 亚美时报 }\end{array}$ & Weekly & Free & 1987 & 20,000 & $\begin{array}{l}\text { Flushing. } \\
\text { NY }\end{array}$ & a \\
\hline $\begin{array}{l}\text { Brooklyn Chinese Monthly } \\
\text { 号外月刊 }\end{array}$ & Monthly & Free & 1999 & 35,000 & $\begin{array}{l}\text { Brooklyn, } \\
\text { NY }\end{array}$ & a \\
\hline $\begin{array}{l}\text { Chinese Consumer Weekly } \\
\text { 今周刊 }\end{array}$ & Weekly & Free & 1997 & & Edison, $\mathrm{NJ}$ & $\mathrm{b}$ \\
\hline $\begin{array}{l}\text { Chinese News Weekly } \\
\text { 新象周刊 }\end{array}$ & Weekly & Free & 1995 & 15,000 & $\begin{array}{l}\text { Metuchen, } \\
\text { NJ }\end{array}$ & $\mathrm{a}$ \\
\hline $\begin{array}{l}\text { Duowei Times } \\
\text { 多维时报 } \\
\text { www.duoweotimes.com }\end{array}$ & Weekly & Free & 1999 & & Edison, NJ & $a \& b$ \\
\hline $\begin{array}{l}\text { Global Chinese Times } \\
\text { 新州周報 }\end{array}$ & Weekly & Free & 1991 & & Edison, $\mathrm{NJ}$ & b \\
\hline $\begin{array}{l}\text { Liberty Times } \\
\text { 自由時報 }\end{array}$ & Daily & $\begin{array}{l}\text { Free in NYC, } \\
\text { Newsstand in } \\
\text { NJ, } \\
\text { Subscription }\end{array}$ & $\begin{array}{l}1995 \\
\text { (ceased } \\
\text { publishing } \\
\text { in June } \\
2008 \text { ) }\end{array}$ & 30,000 & $\begin{array}{l}\text { Flushing. } \\
\text { NY }\end{array}$ & $\mathrm{a}$ \\
\hline $\begin{array}{l}\text { New York Community } \\
\text { Times } \\
\text { 纽约社区报 }\end{array}$ & & & 2003 & & $\begin{array}{l}\text { Flushing, } \\
\text { NY }\end{array}$ & $\mathrm{b}$ \\
\hline $\begin{array}{l}\text { NJ Chinese Living } \\
\text { 新泽西生活报 }\end{array}$ & Weekly & Free & & & $\begin{array}{l}\text { South } \\
\text { Plainfield, } \\
\text { NJ }\end{array}$ & b \\
\hline $\begin{array}{l}\text { Sino Monthly } \\
\text { 汉新月刊 } \\
\text { www.sino-monthly.com }\end{array}$ & Monthly & $\begin{array}{l}\text { Free, } \\
\text { Subscription }\end{array}$ & 1991 & 17,000 & Edison, NJ & $a \& b$ \\
\hline $\begin{array}{l}\text { The SinoAmerican Times } \\
\text { 侨报周刊 } \\
\text { wwww.sinovision.com/newsp } \\
\text { aper.php }\end{array}$ & Weekly & Free & 2007 & $\begin{array}{l}30,000 \\
(\mathrm{NYC}) \\
20,000(\mathrm{NJ})\end{array}$ & $\begin{array}{l}\text { New York, } \\
\text { NY }\end{array}$ & b \\
\hline
\end{tabular}

(Sources: a. Scher 2004.

b. This author's investigation)

Table 3: Local and Regional Chinese-language Newspapers (Greater Toronto Area) 


\begin{tabular}{|c|c|c|c|c|}
\hline Title & Frequency & $\begin{array}{l}\text { Distribution } \\
\text { Method }\end{array}$ & $\begin{array}{c}\text { Year } \\
\text { Founded }\end{array}$ & Circulation \\
\hline $\begin{array}{l}\text { Canada China News } \\
\text { 中华导报 } \\
\text { http://www.canadachinanews.com }\end{array}$ & & & 1995 & \\
\hline $\begin{array}{l}\text { Chinese Canadian Times } \\
\text { 加中时报 } \\
\text { http://www.cctimes.ca }\end{array}$ & Weekly & Free & 2002 & 13,000 \\
\hline $\begin{array}{l}\text { Chinese News } \\
\text { 大中报 } \\
\text { http://www.chinesenewsgroup.com }\end{array}$ & $\begin{array}{l}\text { Three times a } \\
\text { week }\end{array}$ & Free & 1993 & \\
\hline $\begin{array}{l}\text { Global Chinese Press } \\
\text { 环球华报 } \\
\text { http://www.gcpnews.com }\end{array}$ & Twice a week & Free & 2000 & 60,000 \\
\hline $\begin{array}{l}\text { New Star Weekly } \\
\text { 星星生活 } \\
\text { http://news.newstarnet.com }\end{array}$ & Weekly & Free & 2002 & \\
\hline $\begin{array}{l}\text { Today Daily News } \\
\text { 现代日报 } \\
\text { http://www.todaydailynews.com/ }\end{array}$ & Daily & $\begin{array}{l}\text { Subscription } \\
\& \text { Newsstand }\end{array}$ & 2005 & \\
\hline $\begin{array}{l}\text { Very Good News } \\
\text { 华报 } \\
\text { http://www.verygood.ca }\end{array}$ & Weekly & Free & 2004 & 11,000 \\
\hline
\end{tabular}

(Based on the information provided on the web site of each respective newspaper)

The two tables show considerable similarities between the newspapers published in these two areas. Most of the publications are weeklies and are relatively new. There is also a noticeable difference between these two areas. The Toronto newspapers are more likely to have their own web sites than the newspapers in New York-New Jersey, which may be due to the regional variation of hiring affordable information technology talents.

Within each metropolitan area, the newspapers differ by content and geographic coverage. I will illustrate this point with newspapers from the New York-New Jersey region. Some newspapers in this region can reach all the communities within the metropolitan area and even beyond, partly because they have little community-specific content. Their contents are either recycled from other sources or advertisements. The better ones of this group tend to be affiliated with a larger media company. For example, Duowei Times and Chinese Consumer Weekly are affiliated with Chinese Media Net (多维媒体公司), which owns several other Chinese language media outlets. SinoAmerican Times is a product of SinoVision (美国中文电视), a New York-based Chineselanguage TV network. The other type of newspapers focuses on covering a smaller community 
in the region and therefore can be considered pure community press. These newspapers tend to provide more unique or original content. The examples in this group are Asian American Times, Brooklyn Chinese Monthly, and New York Community News in New York as well as Chinese News Weekly, Global Chinese Times, and Sino Monthly in New Jersey.

\section{Issues for Libraries}

The above information about the historical and contemporary Chinese-language newspapers in North America will help us address the issues facing the library community, particularly in respect to locating, collecting, preserving, and digitizing these newspapers. In the following, I will discuss both the accomplishments in these areas and the challenges ahead.

\section{Locating newspapers}

To access the newspapers, a researcher needs to know what newspapers are available and where they can be found. One of the traditional ways for the library community to provide access is to compile a union list of newspapers. The first union list of Chinese newspapers published in North America came out in 1976, as a result of the collaboration between a librarian, Karl Lo, and a pioneering scholar in Chinese American studies, Him Mark Lai. Altogether, they found 252 Chinese-language newspapers and periodicals published in the United States and Canada in the period from 1850s to 1975 and indicated the holding libraries as well (Lo \& Lai, 1977). More recently, the Overseas Chinese Documentation Center at Ohio University developed an online searchable database for overseas Chinese newspapers and journals (http://132.235.47.66/opac), which includes publishing information of 402 titles from North America (342 from the United States and 60 from Canada), but not the information about the holding libraries, which means that a researcher has to use other tools to find where a particular publication is available.

Union catalogs such as the WorldCat from OCLC would be an ideal tool for identifying the holding library of a particular title. But in respect to the Chinese newspapers, the efficacy of library catalogs is compromised by the existence of variant titles and transliterations and the lack of cross reference in the cataloging records. Most of the Chinese newspapers published in North America have a parallel English name, which may or may not be the exact translation of the Chinese name. For example, the World Journal is the direct translation of 世界日报, but the Chinese Press is not the exact translation of 侨报. To the English speakers, a newspaper may be known in its English name, or in its romanized (or transliterated) form. When we take into account the differences of pronunciations between Chinese dialects (particularly Cantonese vs. Mandarin) and the changes of Chinese romanization system since 19th century, things could become much more complicated.

A case in point is the Golden Hills' News, the first Chinese newspaper published in North America. It has various names and transliterations used in different contexts:

- 金山日新录, the title in Chinese characters, usually appearing in Chinese-language writings.

- Golden Hills' News, the parallel English title, used in many English-language works. 
- Kim Shan Jit San Luk, the older romanization rendered from Cantonese pronunciation, used in some English writings, such as Karl Lo (1971).

- Jin shan ri xin lu, the pinyin romanization rendered from Mandarin pronunciation, used in the library cataloging records (but quite a few libraries mistakenly use "jin san ri xin $l u$ " instead).

If one variant title or romanization is missing or misspelled in the cataloging records, problems are bound to happen when researchers try to retrieve the title via the online catalog. A test with Golden Hills' News in WorldCat will confirm that.

To help researchers locate the newspapers, a short-term solution is to enhance the cataloging records by adding variant titles or romanization to the record (and correcting mistakes). In the long run, we may need to refine specialized reference tools.

\section{Keeping track of contemporary publications}

Most newspapers published since 1970s have not made their way into the library collections yet. Therefore, keeping track of these newspapers is both a challenge, since there is no single best source of information on them, and a necessity, because librarians need to know what have been published in order to develop their collections.

As to the contemporary Chinese newspapers in the United States, Yan Ma, a librarian turned library science professor, surveyed editors of Chinese American newspapers and periodicals twice: one in 1987 and the other in 1995/96 (Ma, 1989 \& 1999). In 1987, she sent out a questionnaire to 66 newspaper and periodical editors and received 38 responses; in 1995/96, 137 questionnaires were sent (42 were returned undeliverable) and 51 editors responded. Ma was interested in "Chinese American" publications. So her surveys covered both English and Chinese publications, ranging from daily newspapers to general interest periodicals to academic journals. Ma's surveys probably only covered a small percentage of the Chinese-language press available at that time. Nevertheless, in these two surveys, Ma identified each newspaper's title, location, editor, starting date, circulation number, frequency, and distribution method, and therefore captured snapshots of some Chinese-language publications at two different points of time. Based on her 1995/96 survey, Ma also tried to examine the web presence of these newspapers (Ma, 2003).

One of the lessons I learned from my study is that information about the Chinese press, especially the small ones, is more likely to be captured by specialized regional directories of newspapers (e.g., Scher, 2004) rather than the national directory. Also, in the case of currently circulating newspapers, a physical copy of the newspaper or its web site may confirm the starting year and publishing frequency.

To keep track of contemporary newspapers, especially the local or regional publications that tend to be unstable, we may need to employ a variety of sources: questionnaires to the publishers or editors, newspaper web sites, newspaper directories, and direct observations. An ideal solution will be to have librarians working on each metropolitan area and then pool the information together at the national level. 


\section{Collection and Preservation}

On the newspaper preservation front in the United States, the most significant effort was undertaken by the United States Newspaper Program (USNP), funded by the National Endowment for the Humanities. California, given its large number of Chinese newspapers, has microfilmed many historical titles through the USNP program (Chiu, 1997). Other states might also have microfilmed some Chinese newspapers, but probably not to the extent of California. Some titles might have been microfilmed by their own holding libraries independently. As the print copies of the historical newspapers are not widely available, purchasing the microfilms appears to be the only way to build a comprehensive collection.

One of the main challenges is that there is no systematic effort to collect and preserve the Chinese-language newspapers published in recent years. Major Chinese newspapers such as the World Journal may be found in libraries throughout the United States, but they are normally not kept permanently. In New Jersey, my institution and quite a few other libraries have subscriptions to the Sino Monthly (Edison, NJ), a monthly publication devoted to covering the Chinese community. Due to the fact that the Sino Monthly is in magazine format and publishes only once a month, it is relatively easy to keep it as part of the permanent collection than dailies or weeklies. But this is certainly inadequate even for the Chinese community in New Jersey. So what should we do?

As described above, since the 1970s, the Chinese-language press has developed into a two-tiered system: nationwide newspapers and regional/local ones. Each nationwide newspaper usually represents a Chinese subgroup with different geographic origins, such as Hong Kong, Taiwan, and the Mainland China. Consequently, all of them need to be collected and preserved. On the other hand, the regional and local newspapers that cover the same area tend to have a lot of overlap in terms of both community news coverage and even advertisements. Accordingly, it may not be so cost effective to preserve them all. Therefore, a two-tiered arrangement seems appropriate for collecting Chinese newspapers published in recent years: the national libraries and research libraries of national prominence will be responsible for the nationwide newspapers, while the state/provincial libraries and research libraries in the region will take care of the regional and local newspapers. Regarding the regional or local newspapers, we need carefully examine the content and reputation of each title in relation to its competitors and try to select the better ones for the library collections.

\section{Digital Issues}

Libraries in both the Unites States and Canada have taken steps to digitize historical Chineselanguage newspapers. In Canada, Simon Fraser University, in collaboration with the University of British Columbia Libraries, digitized a significant portion of The Chinese Times (大汉公报) (Minkus, 2004). In the United States, libraries in the University of California system digitized the 1900-1904 issues of the Chung Sai Yat Po (中西日报) ("Guide to the Chung Sai Yat Po Newspaper Collection"). Sporadic issues of other titles may have also been digitized, such as the Golden Hills' News mentioned before. 
Text recognition is one of the biggest technical challenges for digitizing historical newspapers. The Chinese newspaper digitization projects mentioned above have not overcome the obstacle of text recognition. They provide only scanned images. As a result, users cannot conduct full text search, which limits the utility of the digital version. Understandably, the text recognition technology for Chinese is most advanced in China, where Chinese is the native language. Therefore, international collaboration may be necessary in order to improve the digitization of these Chinese-language publications.

Separate from the library digitization projects, major Chinese-language dailies are providing more and more digital content on their web sites. The World Journal is a good example. On its web site (worldjournal.com), users can browse the content from the last seven days, and significant amount of previous contents are archived and can be retrieved via web search engines. It also provides the digital version of the same day's newspaper online for free. Therefore, preserving the digital contents of major dailies may be an area that the library community and newspapers can work together.

\section{References}

Anonymous. (1854, May 27). Chinese exodus. Golden Hills' News, p. 1.

Chen, D. W. (1995, April 16). With affluent Chinese moving in, A press war begins to heat up. New York Times. Retrieved January 3, 2008, from http://query.nytimes.com/gst/fullpage.html?res=990CE4DE103AF935A25757C0A963958260.

Chiu, K. (1997). Access to the past of a nation of immigrants: Asian language newspapers in the United States. Journal of East Asian Libraries, 112, 1-8.

Guide to the Chung Sai Yat Po Newspaper Collection. Retrieved April 14, 2008, from http://content.cdlib.org/ark:/13030/kt0g5016h6/.

Hua, V. (2007, February 27). Clinton staff's gaffe with local ethnic papers. San Francisco Chronicle, p. B3.

Huntzicker, W. (1995). Chinese-American newspapers. In Outsiders in 19th-Century Press History: Multicultural Perspectives. Bowling Green, OH: Bowling Green State University Popular Press.

Kwong, P., \& Miscevic, D. (2005). Chinese America: The Untold Story of America's Oldest New Community. New York: New Press.

Lai, H. M. (1977). A short history of Chinese journalism in the United States and Canada. In Chinese Newspapers Published in North America, 1854-1975 (pp. 1-16). Washington, DC: Center for Chinese Research Materials, Association of Research Libraries.

Lai, H. M. (1987). The Ethnic Press in the United States: A Historical Analysis and Handbook (pp. 27-43). Westport, CT: Greenwood Press. 
Lai, H. M. (1990). The Chinese press in the United States and Canada since World War II: A diversity of voices. Chinese America: History and Perspectives,.4, 107-155.

Leung, J. (2007). Sing Tao Daily's overseas edition and the globalization of Chinese language newspapers (in Chinese). Chinese America: History \& Perspectives, 21, 181-182.

Li. (1854, May 27). Untitled. Golden Hills' News, p. 1.

Li, W. (1998). Anatomy of an ethnic settlement. Urban Studies, 35(3), 479-501.

Lin, W. Y., \& Song, H. (2006). Geo-ethnic storytelling: An examination of ethnic media content in contemporary immigrant communities. Journalism, 7(3): 362.

Lo, K. (1971). Kim Shan Jit San Luk: The first Chinese paper published in America. Bulletin of the Chinese Historical Society of America, 6(8).

Lo, K., \& Lai, H. M. (Eds.). (1977). Chinese newspapers published in North America, 18541975. Washington, DC: Center for Chinese Research Materials, Association of Research Libraries.

Ma, Y. (1989). Chinese American newspapers and periodicals in the United States. Ethnic Forum, 9(1-2), 100-121.

Ma, Y. (1999). Chinese-American newspapers and periodicals in the United States: An analysis of a national survey. The Serials Librarian, 35(4), 63-69.

Ma, Y. (2003). Chinese American newspapers and periodicals in the United States and their web presence. Serials Review, 29(3), 179-198.

Miller, S. M. (1987). Introduction. In The Ethnic Press in the United States: A Historical Analysis and Handbook (pp. X-xxii). New York: Greenwood Press.

Minkus, K. (2004, April). History online. Aq: The Magazine of Simon Fraser University. Retrieved May 1, 2008, from http://www.sfu.ca/aq/archives/april04/features/history.html.

Scher, A. (2004). Many Voices, One City: The IPA Guide to the Ethnic Press of New York and New Jersey Metropolitan Area. San Francisco, CA: Independent Press Association.

Sun, Y. (1998). San Francisco's Chung Sai Yat Po and the transformation of Chinese consciousness, 1900-1920. In Print Culture in a Diverse America. Urbana: University of Illinois Press.

Wen, X. (2005). Founding of the Chinese Revolutionary League in America. Chinese America: History \& Perspectives, 19, 21-42. 
Wilson, C., Gutierrez, F., \& Chao, L. M. (2003). Racism, Sexism, and the Media: The Rise of Class Communication in Multicultural America. Thousand Oaks, CA: Sage Publications.

Yang, T. (2005). English-language Serials in Pre-revolution China: Final Report. New Haven, CT: Yale University Library. Retrieved April 14, 2008, from http://www.library.yale.edu/scopa/grants/2004fin2.htm.

Zhao, X. (2006). Disconnecting transnational ties: The Chinese Pacific Weekly and the transformation of Chinese American community after the Second World War. In Media and the Chinese diaspora: community, communications, and commerce (pp. 26-41). New York: Routledge.

Zhou, M., Chen, W., \& Cai, G. (2006). Chinese language media and immigrant life in the United States and Canada. In Media and the Chinese diaspora: community, communications, and commerce (pp. 42-74). New York: Routledge.

This article is based on a paper previously presented at the 2008 IFLA Conference in Quebec City, Canada. I wish to thank my colleagues in the Rutgers University Libraries for many stimulating conversations about this study. 